\title{
Impact of micro-environmental factors on survival, reproduction and distribution of Oncomelania hupensis snails
}

Mao-Mao Liu' ${ }^{1 \dagger}$, Yun Feng ${ }^{2,3,4 \dagger}$ and Kun Yang ${ }^{1,2,3,4^{*}}$

\begin{abstract}
Background: Schistosomiasis japonica is a chronic parasitic disease that seriously harms people's health. Oncomelania hupensis is the only intermediate host of Schistosoma japonicum. The micro-environmental factors surrounding the snail have a great impact on the survival, growth and reproduction of $O$. hupensis, but there are few relevant systematic analyses until the present. This scoping review aims to identify and summarize the micro-environmental factors that greatly affect $O$. hupensis, and to find gaps in research thus to provide directions for future in-depth studies.

Main body: This scoping review searched databases with search terms of the combinations of "Micro(-)environment", "Oncomelania" and their expanded aspects. A total of 133 original articles were recruited. Predefined data fields were extracted including research methods, influencing factors, and their effects on 0 . hupensis. Most studies focused on vegetation factors (54.1\%), and other factors noted were soil composition (27.8\%), water environmental factors (24.1\%), and predator (3.0\%), respectively. The factors with positive impacts included water level, pH value, soil temperature, soil humidity, the coverage and height of vegetation at suitable levels. This could provide more detailed information for $O$. hupensis habitat identification and prediction. The factors with negative impacts included plant extracts, snail control and disease prevention forests, and microorganisms with molluscicidal activities. It revealed a potential application as ecological molluscicides in the future. Factors such as physico-chemical properties of water, soil chemistry showed a gap in scientific studies, thus required further extensive research.

Conclusions: Micro-environmental factors including water quality, soil composition as well as the technology and application of biomolluscicides (plant extracts and microorganisms) deserve more attention. Relative study findings on micro-environment have good potentials in snail control applications. Further studies should be implemented to investigate the impact of micro-environmental factors on snails and close the research gaps.
\end{abstract}

Keywords: Oncomelania hupensis, Micro-environment, Survival, Reproduction, Distribution, Impact

\section{Background}

Schistosomiasis japonica is a zoonotic disease caused by Schistosoma japonicum, which seriously harms people's health, mainly lead to colon and liver lesions [1]. It

\footnotetext{
*Correspondence: yangkun@jipd.com

${ }^{\dagger}$ Mao-Mao Liu and Yun Feng-Co-first authors

1 Nanjing Medical University, 101 Longmian Avenue, Nanjing 211166, Jiangsu, People's Republic of China

Full list of author information is available at the end of the article
}

is currently endemic in China, Indonesia and the Philippines [2]. In China, a total of 30170 patients with advanced schistosomiasis japonica were reported in 2019 [3]. The prevention and treatment of schistosomiasis should not be ignored, including the control of the intermediate host snails.

Oncomelania hupensis is the only intermediate host of $S$. japonicum [4]. The distribution of S. japonicum infection is determined by the distribution of O. hupensis [5]. The control of $O$. hupensis can fundamentally reduce the 
infection rate of the population, which is essential for the prevention of schistosomiasis. Environmental factors have a great influence on the survival, growth and reproduction of snails [6-9]. Many researches focus on macro-environment factors, such as temperature, climate, rainfall. However, limited systematic analysis are available to investigate the effect of micro-environmental factors which is physically surrounding O. hupensis. Such micro-environmental factors include water quality, water level, soil, and vegetation. All are important to design an effective snail control strategy for the snail intermediate host $[10,11]$.

We hereby systematically reviewed the relevant microenvironmental factors with the following three purposes: First, we aimed to explore the impact of micro-environmental factors on the survival, reproduction and distribution of $O$. hupensis; second, we expected to identify the essential micro-environmental factors that greatly affect the snail distribution; and finally, we would like to find gaps in research thus provide directions for future indepth studies.

\section{Methods}

\section{Search strategy and selection criteria}

We searched five Chinese and English databases [PubMed, EBSCOhost, Web of Science, China National Knowledge Infrastructure (https://www.cnki.net/), and Wanfang (http://www.wanfangdata.com.cn/index.html) database] with no restriction on time. The last retrieval time was December 2019. Search terms were the combinations of "Micro(-)environment", "Oncomelania" and their expanded aspects including water environment, soil environment and vegetation, snail subspecies and other identified search terms (see Additional file 1).

After removing duplicated articles, two authors screened the titles and abstracts of the articles according to the following inclusion criteria, respectively: (i) the article described impact of micro-environmental factors on the survival, reproduction and distribution of $O$. hupensis; (ii) only original studies were included. Articles without full text available were excluded. The exclusion criteria: (i) Not related to Oncomelania and micro-environment; (ii) not described or related to the impact of micro-environment on Oncomelania; (iii) duplicates in different languages; (iv) duplicates of graduate thesis and other papers by the same author; (v) review articles. The screening process was shown in Fig. 1.

\section{Data extraction}

Two authors extracted the information from the recruited articles, respectively. According to the predefined data fields, the following information was extracted: research methods (experimental research/field investigation), influencing factors (water quality, water level, predator, soil physical and chemical properties, soil microorganisms, O. hupensis control and schistosomiasis prevention forest, plant extracts, plant microorganism, vegetation characteristics etc.), and effects on O. hupensis (positive/ negative/curve/unknown). Positive effect means that the enhancement of micro-environmental factors was beneficial to the survival, reproduction or distribution of $O$. hupensis; negative effect means that the enhancement of micro-environmental factors is unfavorable to that; curve effect means that the relationship between micro-environmental factors and $O$. hupensis is not a simple linear relation, and there could be one or more suitable ranges.

\section{Results and discussion}

A total of 1259 articles were retrieved by searching databases. After removing duplicates, and screening title/ abstract/full-text, a total of 133 articles met the inclusion criteria (Fig. 1).

Among the relevant influencing factors of O. hupensis, water environmental factors, soil environment, vegetation and predator accounted for $24.1 \%, 27.8 \%, 54.1 \%$, and $3.0 \%$, respectively. Water level, water quality, soil temperature, humidity, some chemical indexes, vegetation height, coverage, plant extracts, snail control and schistosomiasis prevention forest, Procambarus clarkia (also known as crayfish) and Ophiocephalus argus (black carp) were mainly involved. Table 1 summarized the included articles and classified them according to relevant conclusions.

As shown in Fig. 2, micro-environmental factors that were beneficial to the growth of $O$. hupensis within a suitable range could be applied to the identification and prediction of the habitats of snails. Factors that negatively affect $O$. hupensis can be used in O. hupensis forecast and control. Factors that were less researched or showed contradictory results, leading to no definite conclusions at present, require more in-depth research.

\section{Micro-environmental factors with snail habitats prediction potentials}

Micro-environmental factors with curve relationship to 0 . hupensis survival

Factors like water level, $\mathrm{pH}$ value, soil temperature and humidity, vegetation coverage and height have a curve relationship with the survival of O. hupensis. There were suitable ranges of the factor indicators, beyond or below which was not conducive to O. hupensis. Water level is an important factor affecting $O$. hupensis, which has been widely studied. After the operation of the Three Gorges Dam on Yangtze River in China, the flooding time was shortened and the water level was lowered relatively, which was not conducive to the survival of $O$. hupensis 


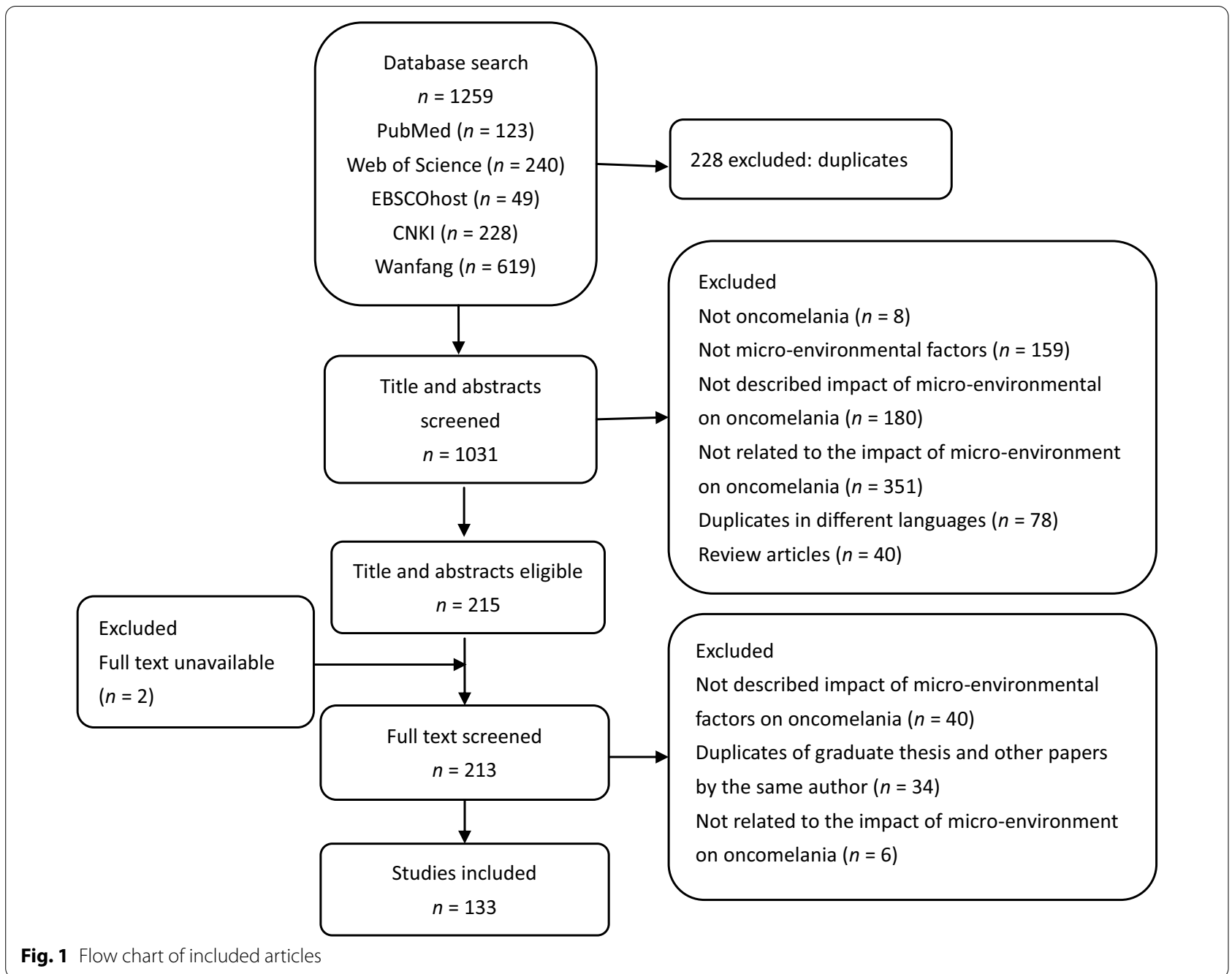

$[12,13]$. Field and experimental studies showed that flooding time influenced the number of eggs laid and the development of eggs, especially in spring when the water flooded ahead of time was not conducive to the reproduction of O. hupensis [14]. The change of water level also affected the distribution height of the snail, which rose accordingly when the water level increased [15]. The change of water level also changed flow velocity of which affected the diffusion of O. hupensis [14]. However, after exploring the relationship between them in a long period, they found that there was not a simple linear relationship, but quadratic or cubic functions and more complex curve relations (with the change of these factors, there might be more than one range which was beneficial to O. hupensis) [16]. Soil temperature, humidity and vegetation height, coverage also affected O. hupensis. Generalized additive models was often used to analyze the relationship between $O$. hupensis density and various micro-environmental factors, and found that soil temperature and humidity content had U-shaped curve or more complex relationship with snail density $[4,11]$.

\section{Suitable ranges of micro-environmental factors for 0 . hupensis survival}

Many researches also believed that there was a suitable range of vegetation height and coverage, which was conducive to the survival of $O$. hupensis. The range of flooding time, $\mathrm{pH}$, soil temperature and humidity suitable for snail survival was $2-7$ months, $5.5-7.9,15-30{ }^{\circ} \mathrm{C}$, and $20-80 \%$, respectively $[4,11,17-25]$; vegetation coverage and height in weed community was $35-90 \%, 15-47 \mathrm{~cm}$, Carex spp. and Triarrhena community (35-95\%, 20-33 cm), single Carex spp. community (16-32\%), single Triarrhena lutarioriparia community $(80-157 \mathrm{~cm})$, Phragmites communis community $(1-100 \%, 72-78 \mathrm{~cm})$, other herb communities (80-100\%, 16-50 cm) [19, $22,26,27]$. Only one article with the subspecies $O . h$. 
Table 1 Classification of included articles by micro-environmental factors covered

\begin{tabular}{|c|c|c|c|}
\hline Micro-environmental factors ( $n, \%)$ & Detailed factor & Effect & Description \\
\hline \multicolumn{4}{|l|}{ Water environment $\left(32^{\mathrm{a}}, 24.1 \%\right)$} \\
\hline Water level $(25,18.8 \%)$ & - & Curve relationship & An optimal range exists \\
\hline \multirow[t]{2}{*}{ Water quality $(7,5.3 \%)$} & Transparency (1) & Positive effects & $\begin{array}{l}\text { Oncomelania hupensis were more likely to } \\
\text { survive in water with high transparency }\end{array}$ \\
\hline & Chemical properties (6) & Need further research & Results from literatures conflict \\
\hline \multicolumn{4}{|l|}{ Soil environment $\left(37^{\mathrm{a}}, 27.8 \%\right)$} \\
\hline \multirow[t]{3}{*}{ Soil properties $(31,23.3 \%)$} & Soil humidity, temperature (18) & Curve relationship & An optimal range exists \\
\hline & Soil pH value (7) & Curve relationship & An optimal range exists \\
\hline & $\begin{array}{l}\text { Soil fertility indexes }\left(8^{b}\right) \text { organic com- } \\
\text { pounds, total N, total P, total K, etc }\end{array}$ & Need further research & Results from literatures conflict \\
\hline Soil microorganisms $(6,4.5 \%)$ & $\begin{array}{l}\text { Aspergillus fumigatus SL-30, Streptomyces } \\
\text { violaceoruber, Xanthobacter autotrophi- } \\
\text { cus, etc }\end{array}$ & Negative effects & $\begin{array}{l}\text { These microorganisms have molluscicidal } \\
\text { activity }\end{array}$ \\
\hline \multicolumn{4}{|l|}{ Vegetation $\left(72^{\mathrm{a}}, 54.1 \%\right)$} \\
\hline Plant extracts $(34,25.6 \%)$ & Root, stem, and leaf extracts & Negative effects & $\begin{array}{l}\text { These plant extracts have molluscicidal } \\
\text { activity }\end{array}$ \\
\hline \multirow{2}{*}{$\begin{array}{l}\text { Land cover vegetation characteristics } \\
\qquad(23,17.3 \%)\end{array}$} & Vegetation height, coverage (12) & Curve relationship & An optimal range exists \\
\hline & $\begin{array}{l}\text { Plant species (11) } \\
\text { Cynodon dactylon, Alternanthera } \\
\text { philoxeroides, Pterocarya stenoptera } \\
\text { community and Nerium indicum } \\
\text { community, Liquidambar formosana, } \\
\text { Sapium sebiferum, etc }\end{array}$ & Negative effects & $\begin{array}{l}\text { O. hupensis are less distributed in areas } \\
\text { with these vegetation types }\end{array}$ \\
\hline $\begin{array}{l}\text { Snail control and schistosomiasis } \\
\text { prevention forest }(14,10.5 \%)\end{array}$ & - & Negative effects & $\begin{array}{l}\text { The implementation of snail control } \\
\text { and schistosomiasis prevention forest } \\
\text { reduces the density of } O \text {. hupensis }\end{array}$ \\
\hline Plant microorganisms ( $1,0.8 \%)$ & Endophyte JJ18 of Pseudolarix amabilis & Negative effects & $\begin{array}{l}\text { These microorganisms have molluscicidal } \\
\text { activity }\end{array}$ \\
\hline \multicolumn{4}{|l|}{ Predator $\left(4^{\mathrm{a}}, 3.0 \%\right)$} \\
\hline $\begin{array}{l}\text { Procambarus clarkia, Ophiocephalus } \\
\text { argus }(4,3.0 \%)\end{array}$ & & Negative effects & $\begin{array}{l}\text { Predation reduces the density of } O \text {. } \\
\text { hupensis }\end{array}$ \\
\hline
\end{tabular}

In the second column, the numbers in brackets represent the number of articles on related factors

a Some of the articles discussed more than one influencing factors

${ }^{\mathrm{b}}$ Two articles specified the subspecies $O$. hupensis quadrasi and showed that organic compounds had a positive impact on the snail survival

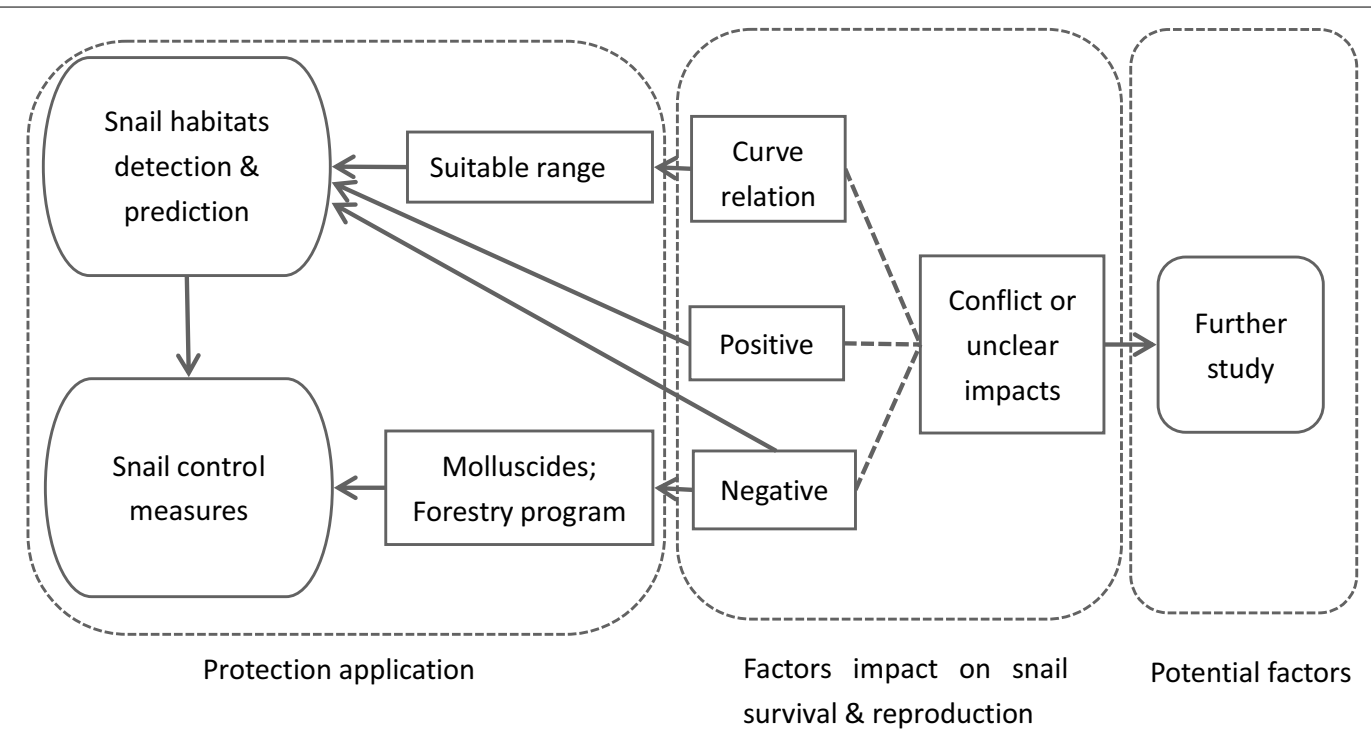

Fig. 2 Application of micro-environment factors on Oncomelania hupensis 
quadrasi was included in our study. The detailed references were also listed in Table 2.

\section{Precise predictive potential of $O$. hupensis distribution using micro-environmental factors}

Exploring the most suitable range for the survival of $O$. hupensis in different regions can be targeted to formulate measures to control snails, and it can also provide basic data for accurate prediction of the distribution of $O$. hupensis. In recent years, geographic information system (GIS) and remote sensing (RS) have been widely used in snail prediction. Using suitable growth conditions of $O$. hupensis, environmental factors were integrated into the prediction model to predict the potential habitats [28]. After combination with the intensity of different environmental factors, the region was divided into different risk levels [5]. Therefore, accurately identified environmental variables and appropriate range can help improve the accuracy of the prediction model and achieve the purpose of snail control.

\section{Micro-environmental factors with snail control potentials}

Among all identified factors, snail control and schistosomiasis prevention forest, plant extracts, microorganisms, predators have been shown to have a negative impact on the snails. Micro-environmental factors that negatively affect $O$. hupensis can be used in schistosomiasis prevention and $O$. hupensis control.

\section{Plant extracts and microorganisms-potential molluscicides}

Some plant extracts were found to have molluscicidal effects on $O$. hupensis. These extracts were phytochemicals or metabolites extracted from plants (Table 3). A total of 18 plant extracts were discovered, all of which

Table 2 Suitable range of micro-environmental factors for Oncomelania hupensis survival and reproduction

\begin{tabular}{|c|c|c|}
\hline Factors & Suitable range & Reference \\
\hline \multirow[t]{4}{*}{ Water level (flood duration) } & $4-5$ months & [23] \\
\hline & 2-7 months & [24] \\
\hline & 24 m (3 months)-25 m (4 months) & {$[20]$} \\
\hline & $130-160$ days & [18] \\
\hline \multirow[t]{3}{*}{$\mathrm{pH}$} & $6.6-7.0$ & [4] \\
\hline & $5.5-7.0$ & [11] \\
\hline & $5.6-7.9^{\mathrm{a}}$ & {$[17]$} \\
\hline \multirow[t]{5}{*}{ Soil temperature } & $16-19^{\circ} \mathrm{C}$ & [22] \\
\hline & $16-20^{\circ} \mathrm{C}$ & [21] \\
\hline & $23-24^{\circ} \mathrm{C}$ & [4] \\
\hline & $24-29^{\circ} \mathrm{C}$ & [11] \\
\hline & $15-30^{\circ} \mathrm{C}$ & [19] \\
\hline \multirow[t]{5}{*}{ Soil humidity } & $0.2-0.3 \%\left(\mathrm{~m}^{3} / \mathrm{m}^{3}\right)$ & [22] \\
\hline & $59-69 \%$ & [4] \\
\hline & $20-60 \%$ & [19] \\
\hline & $60-80 \%$ & [11] \\
\hline & $28-38 \%$ & [25] \\
\hline \multirow[t]{6}{*}{ Vegetation coverage } & 16-32\% (Carex spp.) & [22] \\
\hline & 80-90\% (herb community) & [26] \\
\hline & 60-100\% (herb community) & {$[27]$} \\
\hline & $35-90 \%$ (weed) & [27] \\
\hline & 35-95\% (Carex spp. and Triarrhena lutarioriparia community) & [27] \\
\hline & 1-100\% (Phragmites communis) & [27] \\
\hline \multirow[t]{6}{*}{ Vegetation height } & 80-157 cm (Triarrhena lutarioriparia) & [22] \\
\hline & 16-20 cm (herb community) & [26] \\
\hline & $20-50 \mathrm{~cm}$ (herb community) & [27] \\
\hline & $15-47 \mathrm{~cm}$ (weed) & [27] \\
\hline & 20-33 cm (Carex spp. and Triarrhena lutarioriparia community) & [27] \\
\hline & 72-78 cm (Phragmites communis) & [27] \\
\hline
\end{tabular}

\footnotetext{
a Oncomelania hupensis quadrasi, the other subspecies were not specified
} 


\begin{tabular}{lll}
$\begin{array}{l}\text { Table } 3 \text { Plant extracts } \\
\text { Oncomelania hupensis }\end{array}$ & \multicolumn{1}{l}{ with molluscicidal } & effects on \\
\hline Botanic scientific name & Extracts & Reference \\
\hline Nerium indicum & Triterpenoid saponins & {$[43]$} \\
Arisaema heterophyllum & Calcium oxalate & {$[36]$} \\
Ginkgo biloba & Ethanolic extracts & {$[39]$} \\
Eomecon chionantha & Alkaloid & {$[35]$} \\
Solanum xanthocarpum & Unspecified extracts & {$[46]$} \\
Cinnamomum camphora & Leaf extracts & {$[32]$} \\
Macleaya cordata & Benzo[c]phenanthridine & {$[34]$} \\
& alkaloids & \\
Dioscorea zingiberensis & Saponins & {$[42]$} \\
Reineckia carnea & Unspecified extracts & {$[44]$} \\
Phytolacca americana & Leaf extracts & {$[33]$} \\
Melia azedarach & Leaf extracts & {$[31]$} \\
Buddleja lindleyana & Active ingredient (AlBL) & {$[30]$} \\
Sapium sebiferum & Ethanolic extracts & {$[38]$} \\
Alternanthera philoxeroides & Aqueous extract & {$[41]$} \\
Euphorbia fischeriana & Ethanolic extracts & {$[37]$} \\
Glycyrrhiza uralensis & Glycyrrhiza uralensis extracts & {$[29]$} \\
Rumexjaponicus & Unspecified extracts & {$[45]$} \\
Camptotheca acuminata & Camptothecin & {$[40]$} \\
\hline AlBLActive &
\end{tabular}

AIBL: Active ingredient of Buddleja lindleyana

had a damaging effect on the snail tissue in laboratory settings, mainly affect enzyme activity, interfere with energy metabolism, produce liver toxicity, and reduce the content of glycogen and protein [29-46]. The plant molluscicides were derived from extracts of flowers, fruits, roots, stems, and leaves of plants, and had the advantages of high efficiency, low toxicity, and easy degradation [47]. At present, researches on plant molluscicides are mostly focused on the screening and laboratory research of plants that can produce molluscicidal active substances. A plant molluscicide extracted from the seeds of Camellia oleifera, Luo-Wei, was developed in 2007. It had a good molluscicidal effect, but $4 \%$ Luo-Wei is moderately toxic to Japanese quail and shrimp, and highly toxic to zebra fish [48].

Besides, some microorganisms isolated from the soil, water, plants and snails itself had similar effects [49]. Through O. hupensis snail's toxicity experiments, Aspergillus fumigatus SL-30, Streptomyces violaceoruber, Xanthobacter autotrophicus, strain JJ18 from the endophytic fungi of Pseudolarix amabilis. were proven to have good molluscicidal effects in laboratory settings [50-55]. Results of high-throughput sequencing technology, showed that the abundance, diversity and distribution uniformity of bacterial community in snail gathering areas were better than those in the non-snail breeding areas [56]. These suggest that microorganisms extracted from plants and soil can be used to develop potential molluscicides. These newly emerged microbial molluscicides were efficient and environmental friendly [57]. Researches on plant and microbial molluscicides were mostly at laboratory stage. Further field application tests and product development are not on the agenda. One of the reason could be that the molluscicidal mechanism is still not clear, safety issues on animal or human beings are not addressed and industrializing techniques are not sufficient [49]. Another reason may be that niclosamide is the only snail killer recommended by WHO since 1972 [58], and has a good snail killing effect [59], so the development of new drugs has not been given priority. However, despite of different dosage forms developed to expand its application scope [60], niclosamide remained highly toxic to fish. In this case, we suggest strengthening the study and development of plant-extracting and microbial molluscicides and related technologies, and evaluating their molluscicidal effect and environmental friendliness.

\section{Forestry schistosomiasis control project-mechanism, achievements and challenges}

China launched forestry schistosomiasis control project in 2006, and planted a total of 5.189 billion $\mathrm{m}^{2}$ of $O$. hupensis control and schistosomiasis prevention forest in 10 years [61]. On one hand, the programs were designed to control snails by creating forests to change $O$. hupensis breeding environment [62]. It was found enzyme levels in O. hupensis in the environments of the forestry schistosomiasis control project were different from those in the snail natural habitats. This suggested that snail enzyme and energy metabolism might be interfered by the forests [63]. On the other hand, the snail-inhibiting active ingredients produced and released by plants showed an allelopathic effect on $O$. hupensis to achieve biological snail-inhibition [64]. Liquors of Liquidambar formosana, Sapium sebiferum and Pterocarya stenoptera had strong allelopathy to O. hupensis [65]. This measure has achieved remarkable results. Since the start of this program, the density of snails had decreased by $89.9 \%$, and the density of infected snails had decreased by $95.8 \%$ in 10 years [61]. In addition, the project also increased the forest coverage, and played a positive role in water conservation and soil erosion control as rainwater could be intercepted by tree canopy and soils could be fixed by tree roots [66]. However, afforestation based on a single plant genus (Populus) significantly reduced the original vegetation diversity of the beach [67]. Therefore, different models of forestry projects were needed. The density of $O$. hupensis was different among various plant species. Snails were less distributed in Cynodon dactylon, Alternanthera philoxeroides, Pterocarya stenoptera 
community and Nerium indicum community $[25,68,69]$. Salix babylonica, Liquidambar formosana, Taxodium hybrid 'zhongshanshan', Taxodium ascendens, had better adaptability in marshland and lakeside land, and could be used for forestry project [70]. Agroforestry snail control forests, such as "Juglans regia + Allium sativum", "Juglans regia + Capsicum annuum" and other intercropping patterns, were proved to have good molluscicidal effect and good economic value [71]. In recent years, the forestry schistosomiasis control project faces many challenges. As artificial afforestation will have a certain impact on wetlands ecology, it may have potential conflict with the current trend of environmental protection policies in China. It will be the future direction to design new environmentally friendly forestry schistosomiasis control project with ecological diversity.

\section{Predator}

Procambarus clarkia (also known as crayfish) and Ophiocephalus argus (black carp) competed with O. hupensis for food and ecological space, and were at the upper end of the food chain, which could effectively control and kill O. hupensis [72-74]. Experimental studies and semifield evaluations also demonstrated that crayfish could effectively reduce the population of O. hupensis through predatory interactions [75]. However, the complexity of habitat could strongly affect the intensity of predation in natural communities. In the large-scale wild habitats, the environment was complex, and many different micro-environments could provide suitable refuges for the survival of the snails, which increased the difficulty of predation, especially the predation efficiency of the smaller snails [76]. There was still a lot of uncertainty when this method was used to control snails. Therefore, a long-term field investigation is needed to evaluate the effectiveness and feasibility of this ecological snail control method.

\section{Micro-environmental factors with further researches needed}

The effect of micro-environmental factors like water quality and soil indexes on O. hupensis was also reported. Snails were more likely to survive in water with high transparency [77]. By comparing the differences between the chemical indexes of the water bodies of snail-breeding beach and natural extinction beaches, it was found that the high $\mathrm{pH}$ and the fluorine ion $\left(\mathrm{F}^{-}\right)$content in the water body may be related to the natural extinction of $O$. hupensis [78]. Field investigation in Fu River, China, also showed that the significant increasing in natural mortality of $O$. hupensis might be related to potential water pollution [79]. On the contrary, another field survey [80] showed that exceeding the standard of nitrogen and phosphorus in Dongting Lake, China, leading to eutrophication, was conducive to the survival of $O$. hupensis. The survival experiments of $O$. hupensis in environments with different water quality also indicated that water quality may affect $O$. hupensis, but further evidences were needed [81, 82]. Similarly, studies have shown that there was a correlation between soil fertility indexes (organic compounds, total $\mathrm{N}$, total $\mathrm{P}$, total $\mathrm{K}$, etc.) and snail density, but there was no consistent conclusion [83-85].

Compared to the variety of water/soil physical and chemical properties, the studies focus on their impact to $O$. hupensis were very few. It could be due to the following reasons: (i) There are numerous physical and chemical indicators and components in the water and soil environment. Different types and degrees of pollution have different effects on snails. More well-designed studies are required to reflect the impact of various indicators on O. hupensis; (ii) Short-term field investigations or experiments may not obtain solid evidence of the impact of water quality and soil components on snails, which could be a long-term process; (iii) Long-term retrospective analysis requires the support of historical water quality data with cooperation between multiple departments. Therefore, more targeted researches are needed, and if necessary, it is better to cooperate different environmental factors in the study design. The monitoring of water quality changes can help us to identify potential snail habitats, improve the snail monitoring and early warning system, and provide theoretical basis for existing and new efficient snail control methods. The clear identification of the impacts of environmental factors that can help with the effective reduction of the snail density.

There are nine subspecies of $O$. hupensis, which are from different environments in East and South East Asia. For instance, $O$. $h$. hupensis are from marshland areas near Yangtze River in China, O. h. quadrasi are mainly from the islands in the Philippines while $O . h$. robertsoni from mountainous areas prefers elevated areas [86]. The role of various types of micro-environments playing in snail survival may be different and it could contribute in the design of subspecies-specific snail control approach. For example, snail subspecies that prefers marshland and are closely connected with agricultural activities, like $O$. $h$. hupensis and O. h. nosophora could be efficiently controlled with the environmental transformation methods including ditch lining; while for snails living in hilly areas, such as $O . h$. robertsoni and $O . h$. h. fausti strain, flood storage could be an optimal choice [86, 87]. However, most of the literatures included did not specify the subspecies of $O$. hupensis. More information on different subspecies deserves to be studied in future research.

Most of the included studies were about the relevant impact on $O$. hupensis survival, very few covered 
the impact on its growth and reproduction, which is also essential for the snail population. Possible reason could be the difficulty of laboratory study on $O$. hupensis reproduction. But this kind of study is equally important for snail control strategy and requires more researches in the future.

\section{Conclusions}

This scoping review found many micro-environmental factors including water level, $\mathrm{pH}$ value, soil temperature, soil humidity, the coverage and height of vegetation could affect $O$. hupensis. Successful use of these factors could benefit the surveillance and control of snail habitats. Water quality and soil composition as well as the technology and application of bio-molluscicides which could be more environmentally friendly deserve more attention. We call for further comprehensive studies to improve the accuracy of snail prediction, provide a better theoretical basis for its effective control, and inspire novel control ideas.

\section{Abbreviations}

GIS: Geographic information system; RS: Remote sensing.

\section{Supplementary Information}

The online version contains supplementary material available at https://doi. org/10.1186/s40249-021-00826-3.

Additional file 1. Search strategy by database.

\section{Acknowledgements}

Not applicable.

\section{Authors' contributions}

MML and YF designed this study. MML collected and analyzed data, and wrote the paper. YF has contributed to improving data collection and analysis. YF and $\mathrm{KY}$ are the main contributors to research design, data analysis and improvement of the paper. All authors read and approved the final manuscript.

\section{Funding}

This study is supported by Public Health Department of Jiangsu Province (ZDRCA2016056); Jiangsu Province International Science and Technology Cooperation Project (BZ2020003); Jiangsu Province Provincial Capacity Upgrading Project (BM2018020); Outstanding Youth Fund, Jiangsu Institute of Parasitic Diseases; Wuxi Health Commission Scientific Research Project (Q201812); Public Health Research Center, Jiangnan University (Grant no. JUPH201831).

\section{Availability of supporting data}

The datasets used and/or analyzed during the current study are available from the corresponding author on reasonable request.

\section{Declarations}

Ethics approval and consent to participate Not applicable.
Consent for publication

Not applicable.

\section{Competing interests}

The authors declare that they have no competing interests.

\section{Author details}

${ }^{1}$ Nanjing Medical University, 101 Longmian Avenue, Nanjing 211166, Jiangsu, People's Republic of China. ${ }^{2}$ Jiangsu Institute of Parasitic Diseases, 117 Meiyuan Yangxiang, Wuxi 214064, Jiangsu, People's Republic of China. ${ }^{3}$ Key Laboratory of National Health and Family Planning Commission on Parasitic Disease Control and Prevention, Wuxi, People's Republic of China. ${ }^{4}$ Jiangsu Provincial Key Laboratory on Parasite and Vector Control Technology, Wuxi, People's Republic of China.

Received: 4 October 2020 Accepted: 12 March 2021

Published online: 07 April 2021

\section{References}

1. Chen YY, Liu JB, Jiang Y, Li G, Shan XW, Zhang J, et al. Dynamics of spatiotemporal distribution of schistosomiasis in Hubei Province, China. Acta Trop. 2018;180:88-96.

2. Gryseels B, Polman K, Clerinx J, Kestens L. Human schistosomiasis. Lancet. 2006:368:1106-18.

3. Zhang LJ, Xu ZM, Dang H, Li Y, Lv S, Xu J, et al. Endemic status of schistosomiasis in People's Republic of China in 2019. Zhongguo Xue Xi Chong Bing Fang Zhi Za Zhi. 2019;31:576-82 (In Chinese).

4. Wu JY, Zhou YB, Li LH, Zheng SB, Liang S, Coatsworth A, et al. Identification of optimum scopes of environmental factors for snails using spatial analysis techniques in Dongting Lake Region, China. Parasit Vectors. 2014;7:216.

5. Niu Y, Li R, Qiu J, Xu X, Huang D, Shao Q, et al. Identifying and predicting the geographical distribution patterns of Oncomelania hupensis. Int J Environ Res Public Health. 2019;16:2206.

6. Cheng G, Li D, Zhuang DF, Wang Y. The influence of natural factors on the spatio-temporal distribution of Oncomelania hupensis. Acta Trop. 2016:164:194-207.

7. Hu F, Ge J, Lv SB, Li YF, Li ZJ, Yuan M, et al. Distribution pattern of the snail intermediate host of schistosomiasis japonica in the Poyang Lake region of China. Infect Dis Poverty. 2019:8:23.

8. Wu JY, Zhou YB, Chen Y, Liang S, Li LH, Zheng SB, et al. Three Gorges Dam: impact of water level changes on the density of schistosome-transmitting snail Oncomelania hupensis in Dongting Lake Area, China. PLoS Negl Trop Dis. 2015;9:e0003882.

9. Zhou YB, Zhuang JL, Yang MX, Zhang ZJ, Wei JG, Peng WX, et al. Effects of low temperature on the schistosome-transmitting snail Oncomelania hupensis and the implications of global climate change. Molluscan Res. 2010;30:102-8.

10. Wang HY, Yi HWL, Zhou YB, Liu GM, Zhang ZJ, Peng WX, et al. Impact of micro-environment on Oncomelania hupensis distribution in mountains areas. Zhongguo Xue Xi Chong Bing Fang Zhi Za Zhi. 2010;22:233-7 (In Chinese).

11. Li YP, Wang HY, Zhou YB, He Z, Wan W, Jiang J, et al. Influence regarding micro-ecological environment of snail habitats in lake area on the distribution of snails. Zhonghua Liu Xing Bing Xue Za Zhi. 2010;31:163-6 (In Chinese).

12. Seto EYW, Wu WP, Liu HY, Chen HG, Hubbard A, Holt A, et al. Impact of changing water levels and weather on Oncomelania hupensis hupensis populations, the snail host of Schistosoma japonicum, downstream of the Three Gorges Dam. EcoHealth. 2008:5:149-58.

13. Zhu R, Zhou YB, Zhang LJ, He ZY, Xu XL, Guo JG, et al. The impact of water level changes on the Oncomelania snail habitats in Poyang Lake regions before and after the impoundment of Three Gorges reservoir. Zhonghua Yu Fang Yi Xue Za Zhi. 2013;47:219-22 (In Chinese).

14. Ma W, Liao WG, Kuang SF, Xiao SB, Li PA. On correlation between diffusion of Oncomelania hupensis Gredler and the flow regime in Dongting Lake. Res Environ Yangtze Basin. 2009;18:264-9 (In Chinese). 
15. Li LY, Lu JY, Fan BL, Wang JS. Delayed response of snails'vertical migration on the bottomland to the changed water level. J Yangtze River Sci Res Inst. 2016;33:1-5, 10 (In Chinese).

16. Li YP, He Z, He MZ, Jiang J, Li JX, Zhou YB, et al. Impact of the changing water level on the variance of Oncomelania hupensis populations in Lake Area with general additive model. Zhonghua Liu Xing Bing Xue Za Zhi. 2010;31:1148-54 (In Chinese).

17. Nihei N, Kanazawa T, Blas BL, Saitoh Y, Itagaki H, Pangilinan R. Soil factors influencing the distribution of Oncomelania quadrasi, the intermediate host of Schistosoma japonicum, on Bohol Island, Philippines. Ann Trop Med Parasitol. 1998;92:699-710.

18. An N, Chen NG, Zhong JH, Chen HG, Lin DD, Liu HY, et al. Study on relationship between snail distribution of marshland and changes of water level in Poyang Lake Region. Zhongguo Xue Xi Chong Bing Fang Zhi Za Zhi. 2003;15:429-33 (In Chinese).

19. Jiang JM, He YP, Fei SM, Huang LL, Chen XM, Zhang XD, et al. Relationships between the quantity of Oncomelania and environmental factors of vegetation and soil in hilly and mountainous areas. Wetl Sci Manag. 2006;2:33-9 (In Chinese).

20. Li YP. Impact of water level and elimatic factors on the distribution of Schistosoma japonieum intermediate host Oncomelania hupensis and the identification of snail habitats in Eastern Dongting Lake Areas. Shanghai: Fudan University; 2011. (In Chinese)

21. Ma YK, Zhao A, Yao Z. Application of synthetic model of weights of evidence and certainty factor to study of snail-environmental factor spatial relations. Res Environ Yangtze Basin. 2017;26:1446-55 (In Chinese).

22. Liu H. Relationship between geographical distribution and geographical distribution of snails in typical snail grass in Poyang Lake. Nanchang: Jiangxi Normal University; 2018. (In Chinese).

23. Yang Y, Gao J, Cheng W, Pan X, Yang Y, Chen Y, et al. Three Gorges Dam: polynomial regression modeling of water level and the density of schistosome-transmitting snails Oncomelania hupensis. Parasit Vectors. 2018:11:183.

24. Yang Y, Zheng SB, Yang Y, Cheng WT, Pan X, Dai QQ, et al. The Three Gorges Dam: Does the flooding time determine the distribution of schistosome-transmitting snails in the middle and lower reaches of the Yangtze River, China? Int J Environ Res Public Health. 2018;15:1304.

25. Zhang XD, Yang XC, Peng ZH. Relationships between the surviving Oncomelania and beaches environmental factors. Acta Ecol Sin. 1999;19:123-7 (In Chinese).

26. He XD, Qin JZ, Liu GH. Spatial distribution pattern of Oncomelania hupensis fausti Bartsch and their relationship with vegetation as well as soil in the low hill area along the Yangtze River in Chizhou City. J Anhui Agric Univ. 2013;40:802-8 (In Chinese).

27. Wu G, Su RP, Zhang XD. Relationships between Oncomelania breeding and beach vegetation in the middle and lower reaches of the Yangtze River. Acta Ecol Sin. 1999;19:120-3 (In Chinese).

28. Zhu HR, Liu L, Zhou XN, Yang GJ. Ecological model to predict potential habitats of Oncomelania hupensis, the intermediate host of Schistosoma japonicum in the mountainous regions, China. PLoS Negl Trop Dis. 2015;9:e0004028.

29. Wu CH, Jiang DZ, Li HM. Studies on the mechanism of snail inhibiting activity of Glycyrrhiza uralensis Fisch. extract and its active components. Lishizhen Med Materia Med Res. 2018;29:1837-9 (In Chinese).

30. Han BX, Chen J. Enzyme kinetic analysis of Oncomelania hupensis exposed to active ingredient of Buddleja lindleyana (AIBL). Zhongguo Xue Xi Chong Bing Fang Zhi Za Zhi. 2016;28:388-92 (In Chinese).

31. Gu WB, Zhang Y, Xia SG, Lv D, Zhu D, Wu Y, et al. The effect of Melia azedarach on enzyme histochemistry in Oncomelania hupensis. J Pathogen Biol. 2014;9:16-9 (In Chinese).

32. Yang F, Long EP, Wen JH, Cao L, Zhu CC, Hu HX, et al. Linalool, derived from Cinnamomum camphora (L.) Presl leaf extracts, possesses molluscicidal activity against Oncomelaniahupensis and inhibits infection of Schistosoma japonicum. Parasit Vectors. 2014;7:407.

33. Fang WW. Study on molluscicidal effect of Phytolacca americana Linn against Oncomelania hupensis. Zhenjiang: Jiangsu University; 2011. (In Chinese).

34. Zhong M, Li GY, Zeng JG, Zhang L, Huang KL, She JM, et al. Evaluation of molluscicidal activities of benzo $c$ phenanthridine alkaloids from Macleaya cordata (Willd) R. Br. on snail hosts of Schistosoma japonicum. J Med Plants Res. 2011;5:521-6.
35. Peng F, Liu M, Huang QY, Liu NM, Yang HZ, Sun H, et al. Molluscicidal effect of Eomecon chionantha alkaloids against Oncomelania hupensis snails. Southeast Asian J Trop Med Public Health. 2011;42:289-96.

36. Yu ZS. Molluscicidal effect and mechanism of Benzo[c]phenanthridine alkaloids from Macleaya cordata (Willd) R. Br. Hubei University. 2010. (In Chinese).

37. Wang B, Zhao HM, Lu H. Euphorbia Fischeriana Steud on killing Oncomelania snails and miracidiums of Schistosoma. Anhui Agric Sci Bull. 2010;16:46-8. (In Chinese).

38. Ji HB. Molluscicidal activity and chemical constituents of Sapium sebiferum (L.) Roxb. Nanchang: Jiangxi Normal University; 2010. (In Chinese).

39. Li YY, Chen J, Han BX, Pan GB, Guo DZ. Molluscicidal activities of Ginkgo biloba leaf against the snail Oncomelania hupensis. J Med Plants Res. 2010;4:2466-72.

40. Yin WL. Study on the mechanism of camptothecin in molluscicidal action. Wuhan: Hubei University; 2009. (In Chinese).

41. Tan P, Zhang XJ, Yang JM, Zhang Y. Effect of Alternanthera philoxeroides on enzymic histochemistry of Oncomelania hupensis. Zhongguo Ji Sheng Chong Xue Yu Ji Sheng Chong Bing Za Zhi. 2009;27:11-6. (In Chinese).

42. Cao LW. Isolation, structure analysis and bioactivity of saponins from Dioscorea zingiberensis C. H. Wright. Wuhan: Central China Normal University; 2008. (In Chinese).

43. Zhang Y. Study on extraction, purification, molluscicidal effect, structure activity relationship and allelopathy mechanism of triterpenoid saponins from Nerium indicumMill. Wuhan: Hubei University; 2007. (In Chinese).

44. Chen XM. Application of liquid-phase microextraction in the analysis of phenolic compounds in water and the separation of effective compounds from Reineckia carnea (Andr.) Kunth. Wuhan: Central China Normal University; 2006. (In Chinese).

45. Yang YY, Yan DZ, Zuo JC, Zhu W, Wang WX. The study of the toxic effect of Rumex japonicus Houtt and of EST isoenzymes in Oncomelania hupensis. J Hubei Univ (Nat Sci). 2002;24:354-6. (In Chinese).

46. Wei FH, Xu XJ, Liu JB, Dai YH, Dussart G, Trigwell J. Toxicology of a potential molluscicide derived from the plant Solanum xanthocarpum: a preliminary study. Ann Trop Med Parasitol. 2002;96:325-31.

47. Lu XT, Gu QY, Limpanont Y, Song LG, Wu ZD, Okanurak K, et al. Snail-borne parasitic diseases: an update on global epidemiological distribution, transmission interruption and control methods. Infect Dis Poverty. 2018;7:28.

48. Jia TW, Wang W, Sun LP, Lv S, Yang K, Zhang NM, et al. Molluscicidal effectiveness of Luo-Wei, a novel plant-derived molluscicide, against Oncomelania hupensis, Biomphalaria alexandrina and Bulinus truncatus. Infect Dis Poverty. 2019;8:27.

49. Cheng WT, Zhou YB, Pan X, Song XX, Jiang QW. Advances in researches of molluscicidal microorganisms against Oncomelania hupensis. Zhongguo Xue Xi Chong Bing Fang Zhi Za Zhi. 2016;28:103-7. (In Chinese).

50. Xiao RF, Yang JM, Wang PR, Wu CH. Study on molluscicidal effect of Xanthobacter autotrophicus against Oncomelania hupensis. Zhongguo Xue Xi Chong Bing Fang Zhi Za Zhi. 2005;17:42-4. (In Chinese).

51. Tan P, Yang JM, Xiao R, Zhang Y. Influence of Streptomyces violaceoruber on the enzyme-histochemistry in Oncomelania hupensis. Acta Zool Sin. 2006:52:109-14. (In Chinese).

52. Guo DZ, Chen J. Biological safety of the mouuscicidal ingredient from Aspergillus fumigatus SL-30 isolated from rhizosphere of Phytolacca acinosa. Zhongguo Ji Sheng Chong Xue Yu Ji Sheng Chong Bing Za Zhi. 2012;30:460-3. (In Chinese).

53. Chen L, Zhao JJ, Cao BF, Yu SB, Huang L. Study on the mechanism of snail control by high effective molluscicidal strain. Beijing Agric J. 2014:3-4. (In Chinese).

54. Cui GY, Wang SP, Cheng HB, Wei H, He X, Lvqiu CJ, et al. Screening of molluscacidal microorganisms against Oncomelania hupensis and their effect. Zhongguo Ji Sheng Chong Xue Yu Ji Sheng Chong Bing Za Zhi. 2015;33:234-6. (In Chinese).

55. Guo SB, Chen J, Jia H, Xi C, Nan Z. Molluscicidal experiment of endophytes from Pseudolarix kaempferi Gord. Zhongguo Xue Xi Chong Bing Fang Zhi Za Zhi. 2007;19:285-8. (In Chinese).

56. Tu ZX, Wang XH. Preliminary study to the relationship between Oncomelania hupensis aggregation and microenvironment microbial communities. Jiangxi Sci. 2016;34:400-8. (In Chinese). 
57. Duval D, Galinier R, Mouahid G, Toulza E, Allienne JF, Portela J, et al. A novel bacterial pathogen of Biomphalaria glabrata: a potential weapon for schistosomiasis control? PLoS Negl Trop Dis. 2015;9:e0003489.

58. Fenwick $A$. The role of molluscicides in schistosomiasis control. Parasitol Today. 1987;3:70-3; discussion 70.

59. Li W, You BR, Shi L, Hu HG, Chen XJ, Mei QF, et al. Molluscicidal effects of different formulations of niclosamide ethanolamine salt in marshlands. Zhongguo Xue Xi Chong Bing Fang Zhi Za Zhi. 2018;30:540-3. (In Chinese).

60. Yang GJ, Li W, Sun LP, Wu F, Yang K, Huang YX, et al. Molluscicidal efficacies of different formulations of niclosamide: result of meta-analysis of Chinese literature. Parasit Vectors. 2010:3:84.

61. Fei $S M$, Sun $Q X$, Zhou JX, Jiang JM. A discussion on improving quality and increasing benefits of Forestry Schistosomiasis Control Programs. J Sichuan Forest Sci Technol. 2016;37:18-26. (In Chinese)

62. Yang Y, Zhou YB, Song XX, Li SZ, Zhong B, Wang TP, et al. Integrated control strategy of schistosomiasis in the People's Republic of China: projects involving agriculture, water conservancy, forestry, sanitation and environmental modification. Adv Parasitol. 2016;92:237-68.

63. Zhang SQ, Xu YM, Cao ZG, Wei JG, Yang WP. Impact on activity of AST, ALT, ALP and SDH for snails in project of afforestation for schistosomiasis control with different modes. J Trop Dis Parasitol. 2013;11:125-7, 156. (In (Chinese).

64. Yang X, Sun QX, Zeng Z, Guo W, Zou JX. Discussion on strategy of development of forestry schistosomiasis control programs of China in new period. Zhongguo Xue Xi Chong Bing Fang Zhi Za Zhi. 2018;30:472-5. (In Chinese).

65. Fang JM, Sun QX, Xu Q, Su SX, Dong GP. Liquidambar formosana, a good tree species for control of Oncomelania hupensis and schistosomiasis prevention. Anhui Forest Sci Technol. 2017:43:7-13. (In Chinese).

66. Liu GF, Li K, Zhang CH. Snail control effect and eco-economical benefit of forest for snail control and schistosomiasis prevention in mountainous regions. Zhongguo Xue Xi Chong Bing Fang Zhi Za Zhi. 2011;23:386-9. (In Chinese).

67. Xiao Y, Sun QX, Zhu Z, Wei GZ, Zhou JX. Discussion on strategy of development of forestry schistosomiasis control programs of China in new period. Zhongguo Xue Xi Chong Bing Fang Zhi Za Zhi. 2018;30:472-5. (In Chinese).

68. Zuo JC. Study on the effect and mechanism of Oncomelania control in Pterocarya stenoptera C.DC. community and Nerium indicum Mill community. Wuhan: Hubei University; 2003. (In Chinese).

69. Wu CH, Yi B, Yang JM, Peng Y, Yu CB. Study on molluscicidal effect and mechanism of artificial communities with Alternanthera philoxeroides, Zhongguo Xue Xi Chong Bing Fang Zhi Za Zhi. 2010;22:452-8. (In Chinese).

70. Fang JM, Sun QX, Su SX, Guo WL, Ji LL, Yin H, et al. Screening of suitable tree species for control of Oncomelania hupensis and schistosomiasis prevention in the middle and lower reaches marshlands of the Yangtze River. Anhui Forest Sci Technol. 2019:45:3-10. (In Chinese).

71. Guo YH, Xu DB, Jiang QC, Shi Y, Zhou FL, Yuan QQ. Comprehensive benefits of agroforestry snail control forests in Eryuan County, Yunnan Province. Zhongguo Xue Xi Chong Bing Fang Zhi Za Zhi. 2020;32:384-8 (In Chinese).
72. Bi YY. Study on the factors affecting the predation of Oncomelania snails by Procambarus clarkii. Beijing: Capital Normal University; 2007. (In (hinese).

73. Hong F. Discussion on ecological control technology for schistosomes in river and lake shoals. Yangtze River. 2010;41:102-4. (In Chinese).

74. Xiang H. Procambarus clarkii and Oncomelania hupensis. Encyclopedia knowledge. 2013: 46. (In Chinese)

75. Sulieman Y, Pengsakul T, Guo Y, Huang SQ, Peng WX. Laboratory and semi-field evaluation on the biological control of Oncomelania hupensis snail (Gastropoda: Pomatiopsidae), the intermediate host of Schistosoma japonicum, using Procambarus clarkii crayfish (Crustacea: Cambaridae). Egypt J Biol Pest Control. 2013;23:215-20.

76. Trussell GC, Ewanchuk PJ, Matassa CM. Habitat effects on the relative importance of trait- and density-mediated indirect interactions. Ecol Lett. 2006;9:1245-52.

77. Wang ZX. Faunal survey of aquatic oligochaeta in Zhongshan, south china and preliminary study of quantitative environmental indications by zoobenthos in the Yangtze lakes. Bejiing: Institute of Hydrobiology, Chinese Academy of Sciences; 2007. (In Chinese).

78. Yang Y, Li WB, Chemh WT, Yang Y, Dong SR, Li LH, et al. Relationship between natural extinction of Oncomelania hupensis snails and water chemical properties in Eastern Dongting Lake areas. Zhongguo Xue Xi Chong Bing Fang Zhi Za Zhi. 2019;31:126-33. (In Chinese).

79. He HR, Zhang SP, Zou MX, Li YA, Wang RH, Feng XH. Relationship between water quality and situation of Oncomelania snails in basin of FU river. Zhongguo Xue Xi Chong Bing Fang Zhi Za Zhi. 2004;16:352-4. (In Chinese).

80. Li ZW, Zhang Y, Cui M, Zhou JX, Shi L, Guo L, et al. Spatial distribution of snail and schistosomiasis and its relationship with the water environment quality in Dongting Lake region. Geogr Res. 2013;32:403-12. (In Chinese).

81. Wei WX, Zhang LP, Zhang JP, Zhou M, Zhu JR, Da XR. Study on control strategy and recrudescence factors of snails during urbanization in Tai Lake Plain. Prev Med Tribune. 2011;017:483-6, 489. (In Chinese).

82. Ru DS, Zhe J, Bin YJ. Effect of water and soil of marshilands along Changjiang river without snails on snails growth. Chin Public Health. 2003; 19. (In Chinese).

83. Xiang RD, Xu XW, Xu SW. Influence factors on Oncomelania snails' distribution in marshland of Diaocha Lake. Zhongguo Xue Xi Chong Bing Fang Zhi Za Zhi. 2005;17:67-8. (In Chinese).

84. Qin JX, Tan ZF, Zhang CH. Environment factors and spatial characters of distribution of Oncomcelania snails in islet and beach of Dongting Lake area. J Nat Disast. 2008;17:19-27. (In Chinese).

85. Jiang JM. Research on the habitat characteristics of Oncomelania snail and effects of controlling snails by afforestation in the purple hilly area of Sichuan province. Beijing: Chinese Academy of Forestry; 2013. (In Chinese).

86. Zhou XN. Science on oncomelania Snail. Beijing: Science Press; 2005.

87. Ohmae H, Iwanaga Y, Nara T, Matsuda H, Yasuraoka K. Biological characteristics and control of intermediate snail host of Schistosoma japonicum. Parasitol Int. 2003;52:409-17.

Ready to submit your research? Choose BMC and benefit from:

- fast, convenient online submission

- thorough peer review by experienced researchers in your field

- rapid publication on acceptance

- support for research data, including large and complex data types

- gold Open Access which fosters wider collaboration and increased citations

- maximum visibility for your research: over $100 \mathrm{M}$ website views per year

At BMC, research is always in progress.

Learn more biomedcentral.com/submissions 